\title{
Family Support and Learning Achievement in Junior High School Students During the Covid-19 Pandemic
}

\author{
Nala Zafirah ${ }^{1}$ Raja Oloan Tumanggor ${ }^{1 *}$ Willy Tasdin ${ }^{1}$
}

\author{
${ }^{1}$ Faculty of Psychology, Universitas Tarumanagara, Jakarta \\ Corresponding Author.Email: rajat@fpsi.untar.ac.id
}

\begin{abstract}
Family support is a relationship process in the form of support by providing help and assistance, which is given to each family member. Family support can help students improve learning achievement in the distance learning process carried out from home during COVID-19. This study aims to determine the relationship between family support and learning achievement in junior high school students who carry out distance learning during COVID-19. This research uses quantitative research methods, with a correlational type. Sampling in this study using purposive sampling technique. This study took 223 participants consisting of junior high school students who carried out distance learning during COVID-19 in grades VII, VIII, and IX in Bekasi, West Java, Indonesia. The results of this study indicate that there is no relationship between family support and learning achievement during distance learning during COVID-19, $\mathrm{r}=.088$ with $\mathrm{p}=.188$. This study also shows that family support for junior high school students who carry out distance learning during COVID-19, there are differences when viewed from age and class.
\end{abstract}

\section{Keywords: Family support, learning achievement, Covid-19, junior high school students}

\section{INTRODUCTION}

On March 2, 2020, COVID-19 began to be discovered in Indonesia. President Jokowi made an announcement that there were 2 positive cases of COVID-19 in Indonesia [1]. Since then, the spread has become more widespread and positive cases of COVID-19 have continued to increase in Indonesia. As a result of the very disturbing spread of COVID-19, the Indonesian government issued a policy to deal with the COVID-19 phenomenon by carrying out social distancing, namely maintaining distance. The form of social distancing policy in the realm of education in accordance with Circular Number 4 of 2020 concerning Implementation of Education Policies in an Emergency for the Spread of Coronavirus Disease (COVID-19), is to provide a policy that the teaching and learning process is carried out from home through distance learning.

This policy provides a change in the education system from the previous state. Learning activities are usually carried out directly, namely face-to-face between students and teachers at school, but now learning activities must be carried out at home through distance learning with limited interaction via virtual. This situation has an impact on students. Students experience difficulties in the learning process and are required to understand the use of technology. In addition, students lack guidance from the teacher during the learning process. This statement is in accordance with the results of a survey conducted by UNICEF to students in 34 provinces regarding the main difficulties faced by students during distance learning, namely 38 percent of students said they lacked guidance from teachers, while 35 percent experienced problems in access. internet [2]. This situation proves that the quality of education has become poor and educational goals are hampered, so that student achievement can decline. In accordance with research from Dorn et al. [3] COVID-19 has an impact on the quality of learning which has decreased, so that students affected by COVID-19 will become less skilled. The results of research in Zambia explained that teachers suspected a decline in student achievement as a result of COVID-19 [4]. In addition, it was through personal communication carried out with junior high school teachers that student learning achievement had significantly decreased, as seen from the grades of assignments, daily tests and midterm assessments. Declining learning achievement is influenced by distance learning [5].

In this regard, learning achievement can be defined as the result of learning activities that have resulted in changes in behavior and thoughts of students in a certain period, as evidenced by values in the form of symbols, numbers, letters, and sentences which measure the level of student success [6]. In general, there are two factors that influence learning achievement, namely internal (internal) factors and external (external) factors. Internal factors are factors that come from within students, namely physical (health and body condition) and psychological (interests, talents, intelligence, 
learning methods, neglect, and emotions), while external factors are factors that come from outside of oneself, namely the family environment. , society, school, and nature [7].

These factors must work together to achieve high learning achievement, in order to support good quality education. According to Nurkholis [8], family support has an important role in the achievement of student achievement, because the support and attention of this family determines the success of students in achieving high learning achievement.

Friedman said that family support is the attitude, action and acceptance of each family member. Every student / individual needs family support that can be manifested in the form of love, advice, and attention [9]. Family support can help students improve learning achievement, because during the distance learning process carried out from home, families become teachers as well as supervisors for their children. The form of family support that is expected during the distance learning, is to give more time and attention to children to accompany and guide during the learning process. In addition, the family becomes a place for children to ask questions and ask for considerations related to learning materials. Families can also be a place to complain about problems in the distance learning process.

According to Sari's research [10], there is an effect of self-efficacy and family support on the success rate of learning from home during the COVID-19 pandemic. Self-efficacy and family support have an effect of $60.7 \%$ on the success of learning from home. Selfefficacy provides $40.7 \%$ and family support provides $20.0 \%$ for the success of learning from home during the COVID-19 pandemic. Lara and Saracosti [11] also found that parents who have high involvement have more influence on a child's academic achievement than parents who have low involvement.

On the other hand, research from Pratiwi [12] states that there is a weak positive relationship between parental support and learning achievement. The study resulted in a correlation coefficient (r) of 0.271 and significance (p) $=0.000$. The results showed that $25.9 \%$ of parental support had an impact on low student report cards. However, the results of this study also showed that even though the support of parents was high $(74.1 \%)$ there were still students who had low report cards. This means that family support has no significant effect on student achievement.

The existence of gaps in the results of the above studies and the lack of research that explains the relationship between the two variables, namely family support and learning achievement during the Covid-19 period, makes researchers want to do further research. The aim is to determine the relationship between family support and learning achievement of junior high school students who carry out distance learning.

\section{METHODS}

The sampling technique used in this research is purposive sampling technique, in which the sample is not randomly selected because it has been determined by the researcher and has special characteristics. According to Dörnyei [13] purposive sampling is a type of non-probability sampling, the choice of participants who are chosen deliberately because of the quality of the participants.

The family support measurement tool used in this study is the adaptation process of researchers from Yulianto's research [14]. Yulianto himself used the material and substance of the Family Support Scale (FSS) measurement tool from Friedman et al. [15]. Family support is a relationship process in the form of support by providing assistance and assistance to each family member [16]. This dimension of family support consists of 13 items, namely 13 positive items. An example of a question on the dimensions of informational support is "Did your parents advise you to comply with the rules given in school?" (positive items) Through the results of the reliability test when the researcher did the try out to 30 students, it was found that the measuring instrument of family support in the informational support dimension had a cronbach alpha coefficient of 0.888 . The results of the analysis show that of the 13 items, there is 1 item that is smaller than 0.2 , namely item 13 . After being discarded, there are 12 valid and reliable items in total and the Cronbach alpha coefficient is 0.910 .

The second variable of this research is learning achievement. Learning achievement is an achievement that provides cognitive changes, skills, and attitudes in students, according to their abilities as proven by certain tools or tests and expressed in terms of values as the level of success in the learning process. The measuring instrument used to determine the learning achievement of students in junior high schools who carry out distance learning is the result of the acquisition of values in the form of an academic Achievement Index (IP) or the average score in the report card last semester while studying at the school at the time COVID-19. High and low value seen from the predicate / category. Based on the guidelines for assessing SMP by the Ministry of Education and Culture, there are high and low categories of values based on the length of the interval.

\section{RESULT AND DISCUSSION}

The data description for family support using a scale of 1-4 has a hypothetical mean of the measuring instrument of 2.5 while the empirical mean is 2.78 . Based on this explanation, the empirical mean value is greater than the hypothetical mean. So, it can be said that family support for junior high school students who carry out distance learning in Bekasi is high. 
Furthermore, in each dimension of family support starting from informational support, emotional support, instrument support and assessment support has different empirical means. The empirical mean value on the informational support dimension is 2.88 , the emotional support dimension is 2.71 , the instrument dimension is 2.75 , and the assessment support dimension is 2.80 . The four dimensions of family support have an empirical mean greater than the hypothetical mean. So, it can be said that each dimension of family support for junior high school students doing distance learning during COVID-19 in Bekasi is classified as high.

The lowest empirical mean value is in the emotional support dimension, while the highest empirical mean value is in the informational support dimension. This explains that the dimension of informational support affects participants in obtaining family support for junior high school students who carry out distance learning. For more details, see table 1.

Table 1 Description of family support dimensions

\begin{tabular}{llll}
\hline Family & $\boldsymbol{N}$ & Mean & SD \\
Support & & & \\
\hline informational & 223 & 2.88 & .593 \\
emotional & 223 & 2.71 & .617 \\
instrumental & 223 & 2.75 & .756 \\
appraisal & 223 & 2.80 & .515 \\
Total & 223 & 2.78 & .487 \\
\hline
\end{tabular}

The next data description is the learning achievement taken from the average score of the students' last report card. Through existing calculations, the average score for all students' report cards is 2.56 which means that it is in the range of $84-92$. The KKM standard (minimum completeness criteria) set by the author is based on the KKM average score of the six schools, namely 75 . , there are 13 people $(5.8 \%)$ who are in the excellent learning achievement category, 96 people (43\%) are in the good learning achievement category, 91 people $(40.8 \%)$ are in the moderate learning achievement category, and 23 people $(10.3 \%)$ are in the category of learning achievement is less. The learning achievement category is reviewed based on the SMP assessment guidelines by the Ministry of Education and Culture.

The assumption or normality test uses one sample K-S to determine whether the data is normally distributed or not. Based on the test results, it can be seen that the variables of family support and learning achievement are not normally distributed with $\mathrm{p}<0.05$. So it was decided to test the correlation using the Spearman Rho correlation because the variables were not normally distributed. For more details, see table 2.
Table 2 Normality of the variables

\begin{tabular}{ccc}
\hline Variables & $\begin{array}{c}\text { Kolmogorov } \\
\text { Smirnov } \boldsymbol{Z}\end{array}$ & $\boldsymbol{P}$ \\
\hline $\begin{array}{c}\text { Family support } \\
\text { Learning }\end{array}$ & .074 & .005 \\
achievement & .258 & .000 \\
\hline
\end{tabular}

Researchers tested the hypothesis to find whether the relationship between the two variables was significant, namely family support and learning achievement. Researchers used the Spearman Rho correlation test method because the data were not normally distributed. Data analysis was performed using the SPSS version 24.00 program. The calculation results show that family support with learning achievement has a value of $r$ $(223)=.088$ with $p=.188$. This shows that there is no relationship between family support and learning achievement. For more details, see table 3 .

Table 3 Correlation between family support and learning achievement

Family support

\begin{tabular}{llll}
\hline Spearman's & $\begin{array}{l}\text { Learning } \\
\text { achievement }\end{array}$ & $\mathrm{r}$ & 0.088 \\
& & $\mathrm{p}$ & 0.188 \\
\hline
\end{tabular}

The first dimension is informational support which shows the value of $\mathrm{r}(223)=.090$ with $\mathrm{p}=.180$, the second dimension is emotional support which shows the value of $\mathrm{r}(223)=.034$ with $\mathrm{p}=.616$, the third dimension is instrument support which shows the value of $\mathrm{r}(223)=.131$ with $\mathrm{p}=.051$, and the fourth dimension, namely assessment support, shows the value of $\mathrm{r}(223)=.045$ with $\mathrm{p}=.507$. Based on this statement, the four variables did not show a significant relationship with learning achievement. For more details, see table 4.

Table 4 Correlation between dimensions of family support and learning achievement

\begin{tabular}{llc}
\hline & \multicolumn{2}{l}{ Learning achievement } \\
& $\mathrm{r}$ & $\mathrm{p}$ \\
\hline $\begin{array}{l}\text { Learning } \\
\text { achievement }\end{array}$ & 1.000 & \\
$\begin{array}{l}\text { Informational } \\
\text { support }\end{array}$ & .090 & .180 \\
$\begin{array}{l}\text { Emotional } \\
\text { support }\end{array}$ & .034 & .616 \\
$\begin{array}{l}\text { Instrumental } \\
\text { support } \\
\begin{array}{l}\text { Appraisal } \\
\text { support }\end{array}\end{array}$ & .131 & .051 \\
\hline
\end{tabular}


So this study shows there is no relationship between family support and learning achievement in junior high school students who do distance learning. The results of this study are supported by research by Pratiwi [17] which states that parental support only has a weak positive relationship, because of its presence. other factors that affect learning achievement. In accordance with Sari's research [18] which states that family support only contributed $20.0 \%$ to the success of learning from home during the COVID-19 pandemic, while there are other factors, namely self-efficacy which has a more dominant effect, namely $40.7 \%$. According to Anggraeni et al. [19] students who have high self-efficacy can do assignments more easily, resulting in high learning achievement.

Furthermore, it can be said that family support is not a major predictor of learning achievement. Based on the results of research by Dennis, et al. [20], peer support is a stronger predictor than family support in learning achievement. Peers can provide support that plays a more direct role in learning achievement. According to Richardson and Skinner, peer support can be realized by forming study groups, sharing notes, and experiences in learning [21]. It can only be given by peers to meet resources for learning achievement, while the family cannot provide this form of support.

The results of additional tests on learning achievement in terms of age stated that there was no significant difference. In contrast to the research results from Naderi et al. [22] which states that age is one of the factors that influence learning achievement. In addition, based on different tests carried out on gender and learning achievement, there was no difference. This is different from the research conducted by Wagner et al. [23] which states that student achievement in online learning has differences in terms of gender. Men tend to perform lower than women in online learning.

\section{CONCLUSION}

Based on data analysis, it was found that there was no relationship between family support and the learning achievement of junior high school students who did distance learning. This shows that the two variables tested are not related to each other. Suggestions for further research are to add other variables that can affect learning achievement during distance learning during a pandemic. In addition, further research can take samples with a wider coverage of schools. Suggestion for students is the need to build better relationships with peers. This can be done by sharing experiences, notes, and forming study groups, because good relationships with peers can improve student achievement.

\section{ACKNOWLEDGMENT}

We thank the Directorate of Research and Community Service (DPPM) Universitas Tarumanagara Jakarta which has facilitated us to do this research.

\section{REFERENCES}

[1] Fadli, R. (2020, Maret 2). Begini kronologi lengkap viruscorona masuk Indonesia. Halodoc. https://www.halodoc.com/artikel/kronologi-lengkapvirus-corona-masuk-indonesia

[2] UNICEF. (2020, Juni 16). Indonesia: Survei terbaru menunjukkan bagaimana siswa belajar dari rumah. https://www.unicef.org/indonesia/id/pressreleases/indonesia-survei-terbaru-menunjukkanbagaimana-siswa-belajar-dari-rumah

[3] Dorn, E., Hancock, B., Sarakatsannis, J., \& Viruleg, E. (2020). COVID-19 and student learning in the United States: The hurt could last a lifetime. McKinsey \& Company.

[4] Sintema, E. J. (2020). Effect of COVID-19 on the performance of grade 12 students: Implications for STEM education. Eurasia Journal of Mathematics, Science and Technology Education, 16(7), 1-6. https://doi.org/10.29333/EJMSTE/7893

[5] S.B.K. Dewi, personal communication, October 26, 2020.

[6] Rosyid, M. Z., Mustajab, \& Abdulloh, A. R. (2019). Prestasi belajar (1st ed.). Literasi Nusantara.

[7] Rosyid, M. Z., Mustajab, \& Abdulloh, A. R. (2019). Prestasi belajar (1st ed.). Literasi Nusantara.

[8] Nurkholis. (2013). Pendidikan dalam upaya memajukan teknologi. Jurnal Kependidikan, 1(1), 24-44. https://doi.org/10.24090/jk.v1i1.530 
[9] Safitri, F., \& Yuniwati, C. (2016). Pengaruh motivasi dan dukungan keluarga terhadap prestasi belajar mahasiswa tingkat II prodi D-III kebidanan Universitas Ubudiyah Indonesia. Journal of Healthcare Technology and Medicine, 2(2), 154. https://doi.org/10.33143/jhtm.v2i2.248

[10] Sari, T. T. (2020). Self- efficacy dan dukungan keluarga dalam keberhasilan belajar dari rumah di masa pandemi COVID-19. Education Journal: Journal Education Research and Development, 4(2), 127-136. https://doi.org/10.31537/ej.v4i2.346

[11] Lara, L., \& Saracostti, M. (2019). Effect of parental involvement on children's academic achievement in Chile. Frontiers in Psychology, 10, 1-5. https://doi.org/10.3389/fpsyg.2019.01464

[12] Pratiwi, R. D. (2018). Hubungan dukungan orang tua dengan prestasi belajar siswa kelas VIII SLTP Negeri 6 Yogyakarta. Edudharma Journal, 2(1), 1-16.

[13] Ilker, E., Musa, S. A. B., \& Alkassim, R. S. (2016). Comparison of convenience sampling and purposive sampling. American Journal of Theoretical and Applied Statistics, 5(1), 1-4. https://doi.org/10.11648/j.ajtas.20160501.11

[14] Yulianto, M. S. F. (2018). Hubungan dukungan keluarga dengan prestasi belajar anak Sekolah Dasar Negeri 1 Ringinagung Kecamatan Magetan Kabupaten Magetan [Skripsi]. STIKES Bhakti Husada Mulia Madiun.

[15] Friedman, M. M., Bowden, V. R., \& Jones, E. G. (2010). Buku ajar keperawatan keluarga. EGC.

[16] Friedman, M. M., Bowden, V. R., \& Jones, E. G. (2010). Buku ajar keperawatan keluarga. EGC.

[17] Pratiwi, R. D. (2018). Hubungan dukungan orang tua dengan prestasi belajar siswa kelas VIII SLTP Negeri 6 Yogyakarta. Edudharma Journal, 2(1), 1-16.

[18] Sari, T. T. (2020). Self- efficacy dan dukungan keluarga dalam keberhasilan belajar dari rumah di masa pandemi COVID-19. Education Journal: Journal Education Research and Development, 4(2), 127-136. https://doi.org/10.31537/ej.v4i2.346

[19] Anggraeni, M., Sahrani, R., \& Hastuti, R. (2017). Perbedaan prestasi belajar matematika ditinjau dari self-efficacy dan mathematic anxiety siswa SMP di Depok. Jurnal Muara Ilmu Sosial, Humaniora, dan Seni, 1(1), 201-209. http://dx.doi.org/10.24912/jmishumsen.v1i1.350

[20] Dennis, Jessica M. Phinney, Jean S. Chuateco, Lizette Ivy (2005). The Role of Motivation, Parental Support, and Peer Support in the Academic Success of Ethnic Minority First-Generation College Students, Journal of College Student Development, Vol. 46, Number 3, 223-236. DOI: 10.1353/csd. 2005.0023

[21] Dennis, Jessica M. Phinney, Jean S. Chuateco, Lizette Ivy (2005). The Role of Motivation, Parental Support, and Peer Support in the Academic Success of Ethnic Minority First-Generation College Students, Journal of College Student Development, Vol. 46, Number 3, 223-236. DOI: 10.1353/csd. 2005.0023

[22] Naderi, H., Abdullah, R., Aizan, H. T., Sharir, J., \& Kumar, V. (2009). Creativity, age and gender as predictors of academic achievement among undergraduate students. Journal of American Science, 5(5), 101-112.

[23] Wagner, S. C., Garippo, S. J., \& Lovaas, P. (2011). A longitudinal comparison of online versus traditional instruction. Journal of Online Learning and Teaching, 7(1), 68-73. 